\title{
SEXUALIDADE, IDENTIDADE DE GÊNERO E DIREITOS HUMANOS: DIÁLOGOS COM DOCENTES DE UMA ESCOLA PÚBLICA
}

\author{
Fábio Narduchi de Paula \\ Mestrando do Programa de Pós-Graduação em Humanidades, Culturas e Artes da \\ Universidade do Grande Rio (UNIGRANRIO). Bolsista da Capes. \\ fabionarduchi@uol.com.br \\ Eliane Cristina Tenório Cavalcanti \\ Mestranda do Programa de Pós-Graduação em Humanidades, Culturas e Artes da \\ Universidade do Grande (UNIGRANRIO) Bolsista da Capes. \\ eliane.cavalcanti@hotmail.com.br \\ Juliana Narduch de Paula Mansur \\ Bacharel em Direito e Licenciada em Letras pela Universidade Estácio de Sá \\ Professora da Escola municipal Professor Leopoldo Machado \\ jnarduchi@uol.com.br
}

Palavras-Chave: Educação, Sexualidade, Gênero, Direitos Humanos

\section{INTRODUÇÃO}

O presente trabalho trata de um relato de experiência sobre os achados das discussões em sala de aula com alunos (as) da oitava série da Escola Municipal Maria Quitéria, situada no Município do Rio de Janeiro. O objetivo foi analisar e refletir como a sexualidade e a identidade de gênero são percebidas nas implicações dos discursos e práticas construídos por esses docentes e quais os impactos dessas considerações para naturalização, banalização e diminuição de atos discriminatórios no interior dessa escola. Este trabalho leva em consideração questões de Direitos Humanos que fazem parte do Plano Nacional de Educação em Direitos Humanos (2006) e de Educação em Direitos Humanos do Programa Nacional de Educação em Direitos Humanos, especialmente, a terceira versão desse Programa, intitulado PNDH-3 (2010), como uma forma de ensino que permite trazer para o ambiente escolar a formação de uma abordagem que favoreça o combate de todos os tipos de violência e buscar a justiça social dentro e fora do ambiente escolar. 


\section{DISCUSSÃO}

De acordo com Foucault (1985), a sexualidade é um dispositivo de poder que se constitui historicamente e circunstancialmente. Esse dispositivo compõe os modos de existência dos sujeitos, logo, da produção da subjetividade. Esse dispositivo determina os lugares possíveis que serão ocupados delimitando o que seria da ordem do masculino e do feminino. Assim como a sexualidade, a identidade de gênero estabelece uma dimensão da experiência social perpassada por numerosas questões. Através dela, se articula todo um conjunto de crenças, valores e desejos indicando um espectro do que compreendemos como identidade (LOURO, 1997).

Mott afirma (2000) que o cotidiano escolar se configura como espaço formal adequado para a discussão de temas que tratam da sexualidade e da identidade de gênero. Nesse sentido, a homofobia que é compreendida na concepção de Mott (idem), como sendo o medo, a aversão, ou a discriminação contra sexualidade ou homossexuais, bem como o ódio, a hostilidade ou a reprovação aos homossexuais, é um tema de extrema importância que deve ser discutido por docentes e discentes no ambiente escolar.

De acordo com Junqueira (2009), é preciso compreender o ambiente escolar como espaço privilegiado para a superação de ações discriminatórias e violentas, no que diz respeito à sexualidade e a identidade de gênero. Para o autor, é preciso compreender que não se trata apenas de fazer uma defesa de uma minoria que se julga vitimizada, mas de combater toda e qualquer forma de relação sexista, desigual, opressora e hierarquizada que incidem sobre toda a comunidade escolar. Nesse sentido, o espaço escolar possui um papel fundamental, conforme Louro (1995), para refletir e superar as práticas que possam promover a desigualdade, o preconceito e a discriminação.

\section{METODOLOGIA}

O presente estudo adotou a perspectiva pós-estruturalista. Partimos das reflexões feitas por Foucault (1985), Deleuze (1995), Butler (2003) Furlani (2007), Araújo (2001), Louro (1995), Junqueira (2011) e Prado (2008) para tratar das temáticas propostas. Por meio de grupos focais, foram feitas algumas discussões de temas que tratam da sexualidade e da identidade de gênero durante as aulas de Educação Física com alunos e 
alunas do ensino médio. Foram promovidos debates com situações problemas obtidas em noticiários, em publicações nas redes sociais, em documentários e vídeos sobre as temáticas relativas à sexualidade e a identidade de gênero com a finalidade de saber quais as opiniões dos alunos (as) sobre essas questões.

\section{CONCLUSÃO}

As discussões com os alunos indicaram que existe o desejo de tornar a escola um espaço de valorização da diferença. Constatamos através das opiniões dos alunos que não basta que a escola fale sobre questões acerca da sexualidade e gênero, é preciso que as pessoas que a constroem também estejam dispostas a compreender a existência da diversidade. A inclusão no debate destas temáticas constatou que os docentes têm interesse por questões de identidade de gênero e sexualidade, principalmente quando envolvem abordagens que favoreçam o combate ao sexismo, ao machismo, a misoginia, a discriminação e a violência contra homossexuais e transgêneros, o que na perspectivas dos alunos, contribuiria para uma sociedade mais justa e igualitária.

\section{REFERÊNCIAS}

ARAÚJO, U. F. Os direitos humanos na sala de aula: a ética como tema transversal. São Paulo: Moderna, 2001.

BRASIL. Ministério da Justiça. Secretaria Especial de Direitos Humanos. Direitos Humanos: documentos internacionais. Brasília: SEDH, 2006.

Plano Nacional de Educação em Direitos Humanos (PNEDH). Brasília:SEDH/MEC/MJ/UNESCO, 2006/2007.

Programa Nacional de Direitos Humanos (PNDH). Secretária Especial dos Direitos Humanos da Presidência da República, Brasília: SEDH/PR, 2006/2010.

DELEUZE, Gilles; GUATTARI, Felix. Mil Platôs: capitalismo e esquizofrenia. São Paulo:Editora 34, 1995.

FOUCAULT, M. História da Sexualidade I: a vontade de saber. Rio de Janeiro: Graal, 1986.

FURLANI, J. Educação Sexual na sala de aula: relações de gênero, orientação sexual e igualdade étnico-racial numa proposta de respeito às diferenças. Belo Horizonte: Autêntica Editora, 2007. 
JUNQUEIRA, R. D. Currículo heteronormativo e cotidiano escolar homofóbico. Revista Espaço do Currículo, v. 2, n. 2, p. 208ffi230, 2011.

LOURO, G. L. Gênero, História e Educação: construção e desconstrução. Educação \& Realidade, v. 2. n, 20, p. 101ffi132, jul./dez. 1995.

Gênero, Sexualidade e Educação: Uma perspectiva pós estruturalista.

Petrópolis, Rio de Janeiro: Vozes, 1997.

MOTT, L. Manual de coleta de informações, sistematização e mobilização política contra crimes homofóbicos. Salvador: GGB, 2000.

PRADO, M. A. M.; MACHADO, F. V. Preconceito contra homossexualidades: A hierarquia da invisibilidade. São Paulo: Cortez, 2008. 